\title{
Use of Zoom-Based Learning Media to Increase Interest in Learning During the Covid-19 Pandemic
}

\author{
Erfa Okta Lussianda ${ }^{1}$, Nia Anggraini ${ }^{2}$, Liga Febrina ${ }^{3}$ \\ ${ }^{1,2,3}$ Sekolah Tinggi Ilmu Ekonomi Persada Bunda \\ 1erfachianda10@gmail.com \\ ${ }^{2}$ niaanggraini0414@gmail.com \\ ${ }^{3}$ febrinaliga2013@gmail.com
}

\begin{abstract}
The purpose of this study was to find out to what extent online-based learning media (Zoom) can create student interest in STIE Persada Bunda in learning. This research was conducted for 1 (one) year starting from June 2020 to August 2021. The sample and this research were 87 samples, using the techniquestratified proportional random sampling. .The results found that online learning media (zoom) has an effect on student learning interest, this shows that the better the media provided by the lecturer, the more interested students are in learning by lecturers in the teaching and learning process. If the learning media is more interesting, the student's interest in learning will increase.
\end{abstract}

Keywords: Learning Media, Zoom, Interests, Learning

\section{INTRODUCTION}

The learning process is inseparable from the elements of educators and students. Elements of educators here are teachers (lecturers) while students are students (students) who interact in the teaching and learning process. To create an effective teaching and learning process, an educator must be able or able to collaborate with interesting media, so that students are able or can increase their interest in learning and produce maximum learning outcomes.

To create maximum learning outcomes, it is necessary to have creativity from an educator, one of which is the application of learning media. The application of media in the teaching and learning process is very necessary because the existence of learning media is able to provide its own memory to students.

Learning media is one way to help educators in conveying information in the teaching and learning process, and can also increase the creativity of students and also increase the attention of students in receiving the learning provided by the teacher (lecturer). With interesting media, students will be more motivated to learn and even able to provide encouragement so that students can imagine, discuss and talk with other students.

The development of science and technology (IPTEK) at this time can help educators and students be required to be more creative in the use of learning media, even though science and technology cause many kinds of problems and changes in people's lives. However, it is not denied that educators must be able and able to keep up with the times so that a conducive teaching and learning process is created.

At the present time, namely the COVID-19 pandemic that has hit all parts of the world, including our country, namely Indonesia, where conditions like this require that all work done by humans must be able to use various applications to support the work they do.

Quoting from Kevin in Kompas.com who stated that zoom is a video conferencing that is widely used by various groups such as distance learning or work from home carried out by educators (lecturers) with students (students) because this zoom provides video quality and audio can be maintained even if the internet connection is in an unstable state.

To make it easier for educators and students in the teaching and learning process, the government recommends providing online learning, one of which is using online-based learning media, namely by using zoom media. Persada Bunda High School of Economics is one of the universities that uses learning media using zoom media, this is because the current situation must be required to be able to provide online lectures 
using technology-based media. Thus, educators or lecturers must be able to present teaching materials using these media.

In addition, educators must also be able to increase student interest in the learning process by using this zoom media, based on the author's observations, many students only use this media to fill attendance only but do not follow the teaching and learning process properly. discussions when lecturers provide material in online or online lectures, and also many students turn off the zoom camera when the lecture starts, so this creates a presumption for lecturers whether the student is following and listening to the material delivered or just ignoring the online lecture.

Based on the background above, the authors want to see to what extent this online or online-based learning media can create student interest in learning. For this reason, the authors are interested in conducting research with the title "The Effect of Zoom-Based Learning Media to Increase Student Interest in Taking Lectures on Students of the Persada Mother High School of Economics"

\section{THEORITICAL REVIEW}

As an educator (lecturer), it is necessary to keep up with changes and technological developments, especially those related to learning media. So that it can provide the best learning for students (students).

\section{A. Learning Media}

In accordance with the statement of AECT (Association of Education and Communication Technology) in Arsyad, 2011 media are all forms and channels used in conveying messages and information, viewed from the same point of view, Kemp and Dayton (1985: 3), also suggest that The media also plays a role in the communication process where the media is a sender (transfer) tool that transmits messages from the sender (sender) to the recipient of the message or information (receiver).

Learning media is an aid in the learning process, where using learning media can stimulate thoughts, feelings, attention and abilities or skills of students (students) so that they are able to encourage the learning process. Gagne and Briggs (1975) in Arsyad (2011:4) suggest that learning media includes tools that are physically used to convey the contents of teaching materials, which consist of books, cassettes, tape recorders, video recorders, video cameras, films, slides (pictures). frames), graphics, television, photographic images, and computers.

In general, learning media have the following roles:

1. Clarify the presentation of learning messages so that they are not too verbal.

2. Overcome the limitations of space, time and senses.

3. The use of appropriate and varied learning media can overcome the passive attitude of students.

4. Making human experience from abstract to concrete.

5. Provide stimulus and stimulation to students to learn actively.

6. Can increase students' learning motivation so as to improve learning achievement.

At the present time in this pandemic E-learning is one of the learning media that must be implemented by an educator. E-learning is an abbreviation of Electronic Learning, this is a new way in the teaching and learning process that uses electronic media, especially the internet as a learning system. E-learning is the basis and logical consequence of the development of information and communication technology, e-learning is delivered by utilizing computers and the internet using media or applications.

E-learning learning system can be done with a formal or informal learning system. E-learning formally, is a learning system using a curriculum, syllabus, subjects and tests that have been arranged and arranged based on a schedule that has been agreed upon by the relevant parties.

E-learning can also be done informally with simpler interactions, for example by means of mailing lists, enewsletters or personal websites, organizations and companies that want to socialize certain services, programs, knowledge or skills to the wider community (usually free of charge). ).

[1]Zoom Meeting is a learning media that uses video. The founder of this application is Eric Yuan which was inaugurated in 2011 located in San Jose, California. This application is not only used for learning but is also widely used for office and other matters.

\section{B. Benefits of Learning Media}

[2]The function of visual media attention is the core, namely attracting and directing students' attention to be able to concentrate on the content of the lesson related to the visual meaning displayed or accompanying the 
text of the subject matter. While the affective function of visual media can be seen from the level of enjoyment of students (students) when studying or reading illustrated texts. With images or visual symbols can and are able to arouse the emotions and attitudes of students in the learning process.

The cognitive function of visual media can be seen from visual symbols or images which can facilitate the achievement of the goal to understand and remember the information or messages contained in the image. While the last function is a compensatory function where the learning media can be seen from the results of the study that the presence of visual media provides context for understanding the text and helps students who are weak in reading to organize information in the text and to recall it.

There are several benefits of learning media in the student learning process, namely:

1. Learning will attract more students' attention so that it can foster learning motivation.

2. Learning materials will be clearer in meaning so that they can be better understood by students so as to enable them to master and achieve learning objectives.

3. Teaching methods will be more varied, not merely verbal communication through the words of the teacher, so that students do not get bored and the teacher does not run out of energy, especially if the teacher teaches at every lesson.

4. Students can do more learning activities because they do not only listen to the teacher's description, but also other activities such as observing, demonstrating, exhibiting, etc.

\section{Learning Media Indicators}

There are several indicators of learning media, indicators of learning media are as follows:

1. Facilitate delivery of learning messages

2. Make learning more interesting

3. Make learning more interactive

4. Increase students' positive attitude towards learning materials

5. Increase the effectiveness and efficiency of learning

6. Increase students' enthusiasm for learning

7. Increase interest and motivation to learn

8. Making students (students interact directly with reality)

9. improve the quality of learning

D. Interest to learn

\section{Definition of Interest}

[3] Meanwhile, according to Crow \& Crow (in Djaali, 2008: 121) argues that "interest is everything related to the style of motion that can encourage a person to be able or able to face or deal with people, objects, activities, or experiences stimulated by those activities. alone".

From the above understanding it can be concluded that interest is a sense of interest, attention, and a sense of desire that a person has for something, without coercion and encouragement.

\section{Understanding Learning}

[4]Learning is a series of activities in mind and body in order to obtain a change, namely changes in behavior as a result of individual experiences in interaction with their environment which involve cognitive, affective and psychomotor. On the other hand, even though a person is said to be learning, if his physical and mental activity is low, it means that the learning activity does not really understand that he is doing learning activities.

In other words, learning can be concluded, namely changes from within a person seen from one's knowledge, skills and behavior as a result of the process of interaction with the environment.

\section{Understanding Learning Interest}

Interest is a sense of interest, attention and more desire that someone has for something, without any encouragement and coercion. This interest will settle and develop in a person to get support from his environment in the form of an experience. This experience is obtained from interactions with the outside world, both through practice and through learning. The factors that can lead to interest in learning are encouragement from within the individual, encouragement from social motives and emotional impulses.

\section{E. Indicator of Learning Interest}

Indicators of interest in learning are liking / pleasure, statements of liking, a sense of interest, awareness to learn without being asked, participating in learning activities, paying attention. Meanwhile, according 
to Slameto (2010: 180) indicators of interest in learning are feelings of pleasure, interest, attention, and student involvement.

\section{RESEARCH METHODS}

In accordance with the problems above, this research is classified as descriptive and associative research. Descriptive research is research conducted to determine the value of independent variables, either one or more variables without making comparisons or connecting with other variables. In this study, it will be seen whether there is an influence of online-based learning media (zoom) on student interest in learning at the Persada Bunda High School of Economics (STIE) in Pekanbaru Riau.This research was conducted for 1 (one) year starting from June 2020 to August 2021. The sample and this research were 87 samples, using the techniquestratified proportional random sampling.

\section{RESULT AND DISCUSSION}

By processing data using SPSS version 20, a simple linear regression equation is obtained which can be seen in the table 1.2.

Table 1.2 Simple Linear Regression Analysis Results

\begin{tabular}{|c|c|c|c|c|c|c|}
\hline \multicolumn{7}{|c|}{ Coefficients $^{a}$} \\
\hline \multirow[b]{2}{*}{ Model } & & \multicolumn{2}{|c|}{ Unstandardized Coefficients } & \multirow{2}{*}{$\begin{array}{c}\begin{array}{c}\text { Standardized } \\
\text { Coefficients }\end{array} \\
\text { Beta }\end{array}$} & \multirow[b]{2}{*}{$t$} & \multirow[b]{2}{*}{ Sig. } \\
\hline & & $B$ & Std. Error & & & \\
\hline 1 & (Constant) & 21.110 & 2.756 & & 7.659 & .000 \\
\hline & $\begin{array}{l}\text { Media Pembelajaran } \\
\text { Zoom }\end{array}$ & .526 & .042 & .809 & 12.669 & .000 \\
\hline
\end{tabular}

a. Dependent Variable: Minat Belajar

Based on table 5.1, it can be seen that the regression equation formed is:

$\mathrm{Y}=21.110+0.526 \mathrm{X}$

From these equations it can be explained that:

a.The constant of 21.110 states that if it is assumed that the online learning media (zoom) is very low, the student's interest in learning is 0.526 units.

b. The regression coefficient of 0.526 states that for every additional unit of online learning media (zoom), it is estimated that student interest in learning will increase by 0.526 .

\section{A. Test results $t$}

$\mathrm{T}$ test is used to test the effect of independent variables on the dependent variable individually. Hypothesis testing is done by comparing the value of $t$ count with $t$ table at $5 \%$ alpha.

Judging from table 5.1, if the value of $t$ arithmetic $>t$ table, the hypothesis which states that there is no influence of the independent variable on the dependent variable will be rejected, meaning that the independent variable has a significant effect on the dependent variable.

Conversely, if the value of $t$ count $<\mathrm{t}$ table, the hypothesis which states that there is no influence of the independent variable on the dependent variable will fail to be rejected, meaning that the independent variable has no significant effect on the dependent variable.

$\mathrm{T}$ table value $(\alpha=5 \%$; $\mathrm{df}=85)=\square 1,9888$

$\mathrm{t}$ count $=7,650>\mathrm{t}$ table $=1,9888$ Significant 
This means that there is a significant influence on the online learning media variable (Zoom) on the variable interest in learning.

\section{B. Termination Coefficient (R Square)}

The coefficient of determination is a quantity that shows the amount of variation in the dependent variable that can be explained by the independent variable. In other words, the coefficient of determination is used to measure how far the independent variable explains the dependent variable. The value of the coefficient of determination is determined by the value of $\mathrm{R}$ square as can be seen in table 5.2 below:

Table 5.2 The Result of Calculation of the Coefficient of Determination (R Square)

Model Summary

\begin{tabular}{|l|c|r|r|r|}
\hline Model & R & R Square & \multicolumn{1}{c|}{$\begin{array}{c}\text { Adjusted R } \\
\text { Square }\end{array}$} & $\begin{array}{c}\text { Std. Error of } \\
\text { the Estimate }\end{array}$ \\
\hline 1 & $.809^{\mathrm{a}}$ & .654 & .650 & 5.694 \\
\hline
\end{tabular}

a. Predictors: (Constant), Media Pembelajaran Zoom

Based on the results of the calculation of the Coefficient of Determination, it can be explained that the results of this regression give a value of $\mathrm{R}$ Square $=0.654$, meaning that $65 \%$ of the variation in learning media variables is explained by variations in learning interest variables, while the remaining $35 \%$ is explained by other variables.

\section{CONCLUSION}

Based on research on the use of zoom-based learning media to increase student interest in learning, it can be concluded that online learning media (zoom) has an effect on student learning interest, this shows that the better the media provided by the lecturer, the more interested students are in learning by lecturers in the teaching and learning process. If the learning media is more interesting, the student's interest in learning will increase.

\section{REFERENCES}

[1] D. Haqien e AA Rahman, «Utilization of Zoom Meetings for the Learning Process during the Covid-19 Pandemic», SAP (Arctic Arctic. Education), vol. 5, n. 1, 2020.

[2] SR Candrawati, «Utilization of E-Learning in Learning», Beneficiary. Elearning In Learning, pagg. 172-181.

[3] Nurhasanah e A. Sobandi, «Learning Interest as a Determinant of Student Learning Outcomes», J. Educator. manaj. Office, vol. 1, n. 1, p.m. 128, 2016.

[4] Pane e M. Darwis Dasopang, «Learning and Learning», FITRAHJurnal Kaji. Islamic Sciences., vol. 3, n. 2, p.m. 333, 2017. 